\title{
Glacial Avalanche Hazard's Comparative Geospatial Analysis in Shigar and Shyok Basins
}

\author{
Syed Naseem Abbas Gilany and Javed Iqbal
}

\begin{abstract}
Glaciers of mid latitude region are retreating because of global warming acceleration. The Glacial avalanche hazards cause catastrophe in Shigar and Shyok basins. Using Satellite and Topographic data, assessment of glacial avalanche hazards is conducted in this research. The study presents the glacial avalanche hazard assessment in visible and thermal bands based on various methods of image classification. The Digital Elevation Model (DEM) is incorporated to gauge the indicators of glacial avalanche hazard as orientation, slope and elevation of the glaciers in the study area. The location of a site vis-à-vis a glacier, melting behavior of the glaciers and geo-morphology of the parent surface are taken as indicators of glacial avalanche hazard. The results of the study show that settlements in Shyok basin are found more prone to glacial avalanche hazard in comparison with Shigar basin which has resulted in destruction of infrastructure and heavy loss of human lives.
\end{abstract}

Index Terms-Accumulation, anthropogenic, glacial avalanche, seismic, terminus.

\section{INTRODUCTION}

The formation of glaciers is associated with climate. The growth and inception of glaciers is very much dependent on climatic conditions. The underneath surface forms the threshold circumstances of glacier formation. Different sizes and shapes of glaciers are originated from glaciated landscape. Maximum precipitation zones are outcome of climatic fronts which in turn are associated with glaciated mountainous regions. Glaciers in the Karakoram show long-term irregular behaviour with comparatively frequent and sudden advances [1]. The Central Himalayas receive moisture from the summer monsoons and the western Himalayas from winter and summer fronts. The world's steepest gradient glaciers are present in this region, which generate high glacial activity in the vicinity. Scientific evidence shows that most glaciers in South Asia's Hindu Kush Himalayan region are retreating [2]. In order to build the inventory of glaciers types and to measure the ice reserves quantum in northern areas of Pakistan, the grass root knowledge of glacial historic activity is deemed necessary. To ultimately assess the avalanche trigger phenomenon, the knowledge of glacial mass balance involving altitude of ice cover, glacier storage and downslope ice transfer is very vital. The destruction of costly infrastructure, loss of property and life is caused by glacial avalanche hazards.

Manuscript received June 8, 2017; revised August 18, 2017.

The authors are with the Department of Remote Sensing and Geographical Information System, IGIS, National University of Science and Technology, Islamabad, Pakistan (e-mail: naseemgillani2000@yahoo.com, javed@igis.nust.edu.pk).

\section{A. Objectives}

- The prime objective of the study is to carryout comparative assessment of the glacial avalanche hazards in Shyok and Shigar basins. The core objectives are as following:-

1) Documentation of glaciers and potential glacial avalanche prone glaciers involving associated glacial hazards.

2) Inventory of glacial avalanche hot-spots and hazards using GIS and RS techniques.

\section{B. Study Area}

- The scope of the study encompasses the Shyok and Shigar basins of northern Pakistan. The study area is enclosed by:-

1) Shigar basin bounds $75^{\circ}$ to $77^{\circ} \mathrm{E}$ Long, $35^{\circ}$ to $36^{\circ} \mathrm{N}$ Lat. 2) Shyok basin bounds $75^{\circ}$ to $77^{0} \mathrm{E}$ Long, $34^{0}$ to $35^{\circ} \mathrm{N}$ Lat.

\section{Causes of Avalanche Hazard}

1) Greenhouse Effect. The 'greenhouse effect' is foremost concern that anthropogenic activities can change the climate conditions of the region. Global warming is the substantial increase in temperature of the earth's surface cause of anthropogenic activities.

2) Glacial Decay. An important factor in the origination of the glacial avalanche is the rising global temperature, which causes glacial decay in mountain regions like Shigar and Shyok basins. Due to their altitude, the Alps are typical locations for glaciers, snow or permafrost [3]. The natural processes of glaciation and inter-glaciation occur several times during the hundreds of years. It is evident that glaciers of $\mathrm{HKH}$ region have retreated substantially since the inception of Little Ice Age [4].

\section{Historical Glacial Hazard Events}

1) From a tributary of hushe River of Shyok basin, a debris flow was generated on 27 Jul 2000 at village Kande which destroyed 124 houses.

2) A gigantic glacial flow on 7th Apr 2012, comprising heavy boulders and glaciated mass buried the Gyari camp shown in Fig. 1. The intensity of the flow was so high that it flew the 10,000 liters heavy containers like match sticks. It took 139 human lives and destroyed the complete infrastructure including livestock and historical grand mosque. Glacier descended from a height of 5429 meters and after sliding, it accumulated in $1.4 \mathrm{~km} 2$ with $60 \mathrm{~m}$ height. One of the major cause of glacial avalanche was mean average temperature increased from $-0.3 \mathrm{C}^{\circ}$ to $1.4 \mathrm{C}^{\circ}$ due to global warming (massive anthropogenic activities in Shyok basin by India). 


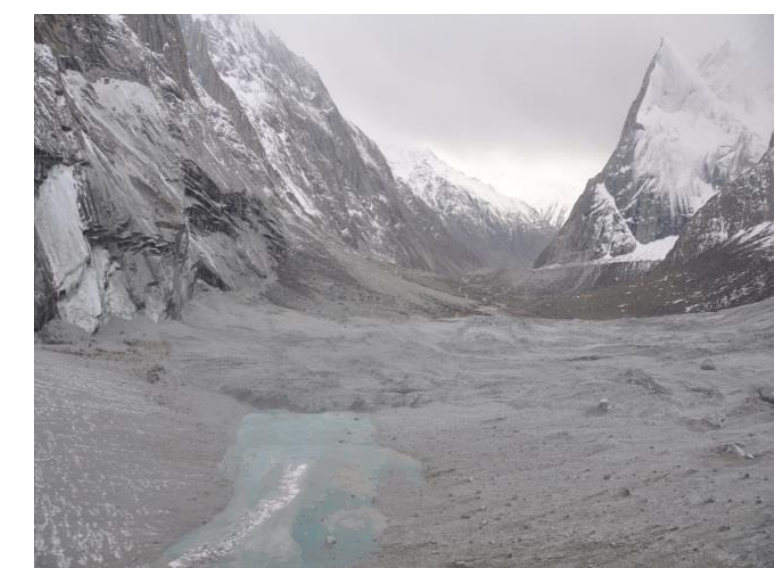

Fig. 1. Glaciated mass flow comprising heavy boulders at Gyari camp.

\section{MAterials AND METHODS}

\section{A. Image Data Set}

The image data of LandSat ETM having a pixel of size 15 $\mathrm{m}$ and $30 \mathrm{~m}$ is used for the delineating the boundaries of the glaciers with spectral differentiation. The analysis of the two river basins of northern areas of Pakistan, Shyok and Shigar is performed using GIS techniques.

\section{B. Topographic Maps}

The topographic maps published by the Survey of Pakistan based on aerial photographs and field surveys. The glaciers identified from the LandSat images are confirmed from the topographic maps.

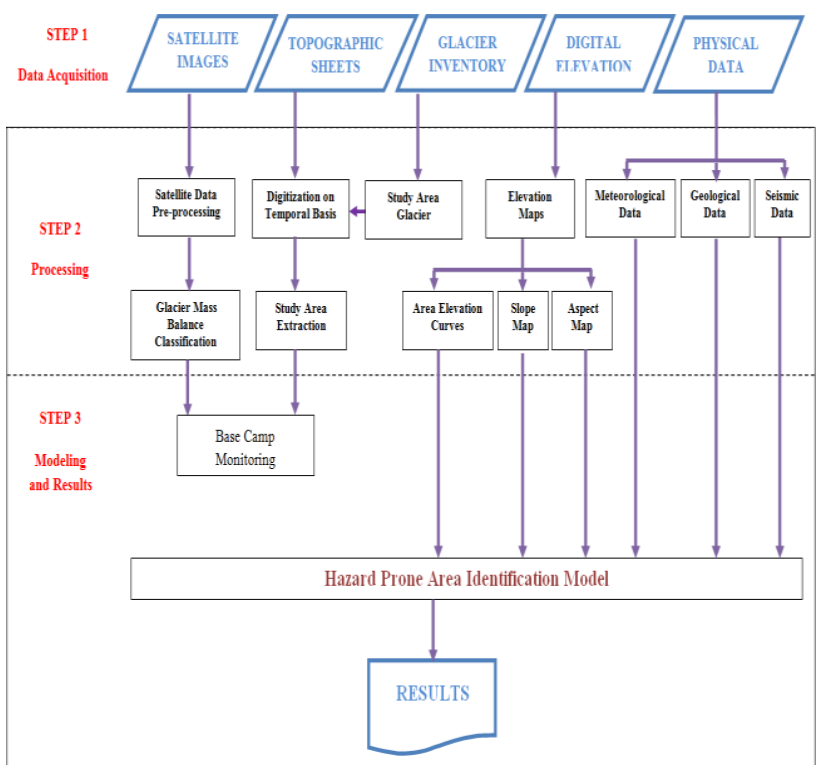

Fig. 2. The methodology flow diagram used for study.

\section{Digital Elevation Model}

Digital Elevation model (DEM) of $30 \mathrm{~m}$ resolution downloaded from the SRTM data and generated from the contours of topographic maps is utilized for obtaining the elevation, slope and aspect of the glaciers. The best estimate of the Upper Indus Basin area is using SRTM DEM [5].

\section{Methodology}

Glaciers identification with respect to glacial avalanche hazards is performed through geospatial analysis. Using height information from DEMs, aspect and slope maps are created. The flow diagram of methodology adopted for the study is as displayed in Fig. 2.

\section{RESUlTS AND DISCUSSIONS}

An inventory of glaciers and digital data bank of knowledge of glaciers and glacial avalanche hazard events would supplement awareness of decision makers to adopt mitigation measures to reduce the vulnerability.

\section{A. Glacial Avalanche Hazard Assessment}

The study of glaciers coupled with field investigations of glacial avalanche hazards using remote sensing methods is carried out. The identification of glaciers coupled with glacial hazard monitoring is carried out with techniques of GIS integrated with remote sensing digital data. The DEM of study area is generated by digitization of topographic map data and with the help of SRTM data. The presentations and better viewing perspectives were generated with the help of GIS techniques. It played a major role in discrimination of land cover types and deciding the bounds of features following the remote sensing rules of classification. Digital elevation model is utilized to generate aspect and slope maps of the study area.

\section{Landsat-7 Bands}

- Band $1(0.45-0.52 \mu \mathrm{m})$

- Band $2(0.53-0.60 \mu \mathrm{m})$

- Band $3(0.62-0.69 \mu \mathrm{m})$

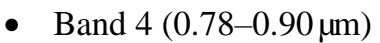

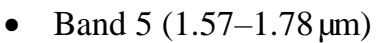

- $\quad$ Band $7(2.10-2.35 \mu \mathrm{m})$

Landsat-7 above mentioned band combinations are utilized for feature discrimination / delineation. Visible, near infrared, middle infrared and far infrared with low gain in $30 \mathrm{~m}$ resolution and with high gain in $60 \mathrm{~m}$ resolution.

Glacier outskirt margins are precisely delineated on the Landsat-7 ETM+ geo-referenced panchromatic mode which is further compared with individual bands and in different color composite bands. The exact boundaries between seasonal snow cover and glaciers are delineated as shown in Fig. 3.

\section{B. Registration of Snow and Ice Masses}

The ice masses and perennial snow are precisely registered. For each ice stream, the measurements of glacier bodies are carefully made with regards to delineated drainage region. Once the differentiation of tributaries from each other is not possible, these are accounted in mainstreams. Furthermore, these are taken as separate streams, if in separate units of a continuous ice mass there is no flow to take place.

Various inventory measurements of a glacier are not affected by snow from debris surfaces and rocks as from remote sensing images the delineation of firn and visible ice is carried out. If the ice is contained by terminal moraines, that is also included in the glaciers measurement. An inactive ice apron of the valley glacier found above its head is considered as part \& parcel of valley glacier. Large enough size perennial snow patches are accounted for the inventory. If an evidence of large ice content is present, then rock 
glaciers are accounted for.

\section{Mean Glacier Thickness and Ice Reserves}

Only selected glaciers of northern areas of Pakistan are measured for glacial ice thickness that to with geophysical techniques. Such information is not available for most of the glaciers in these areas. Measurements of glacial ice thickness in the Tianshan Mountains (China) show that the glacial thickness increases with the increase of its area [6]. The glacial area $(\mathrm{F})$ and ice thickness $(\mathrm{H})$ relationship was found as:

$$
\mathrm{H}=-11.32+53.21 \mathrm{~F}^{0.3}
$$

This formula has been utilized for the estimation of glacier's mean ice thickness. Ice reserves are accounted for glacial area multiplied by mean ice thickness.

\section{Glacier Area}

The accumulation zone and ablation zone form the area of the glacier. The area is given in square kilometers. The Integrated Land and Water Information Systems (ILWIS) database is utilized to calculate the digitized delineated glacier area.

\section{E. Glacier Length}

The total length, length of ablation and mean length combined together to form the total length of glacier. The longest distance along the centerline is termed as the total length of the glacier. The mean length of the glacier is calculated from the mean maximum length of the tributaries of the glacier.

\section{F. Mean Width}

The total area $(\mathrm{km} 2)$ once dividing the by the mean length $(\mathrm{km})$ gives mean width of the glacier.

\section{G. Glacier Orientation}

Eight cardinal directions represent orientation of accumulation and ablation zones of the glacier. Few glaciers are capping like form of an apron of the peak which inherit slope all around. These are termed as open. The accumulation and ablation zones are mostly oriented in similar direction.

\section{H. Glacier Elevation}

The highest value of the crown of the glacier is termed as the highest glacier elevation and the lowest value of the tongue of the glacier is known as lowest glacier elevation. The arithmetic mean of both is graded as the mean value of the glacier.

\section{Glacial Avalanche Hazard Identification}

The glacial avalanche hazards identification is based on following factors:-

1) Location. Location of a settlement vis-a-vis a glacier with faster melting rates is dangerous.

2) Geomorphology. The type of parent material, underneath and adjacent surface.

3) Geo Cover. Starved forested areas and open spaces are more prone to glacial avalanche hazard.

4) Elevation. It is directly related with its magnitude and the probability of occurrence.

5) Aspect. The glaciers of Southern orientation endure more solar radiation causing depletion and are more prone to disasters.

6) Slope. Glaciers having slope in the range of $30-45 \%$ are prone to avalanches and slides glacial hazards.

7) Crevasses. Deeper crevasses engulf snow and ice which ultimately bring avalanche in response to a weather change.

8) Snow and Ice melt. Glacial hazards like avalanches and landslides are triggered by snow and ice melt.

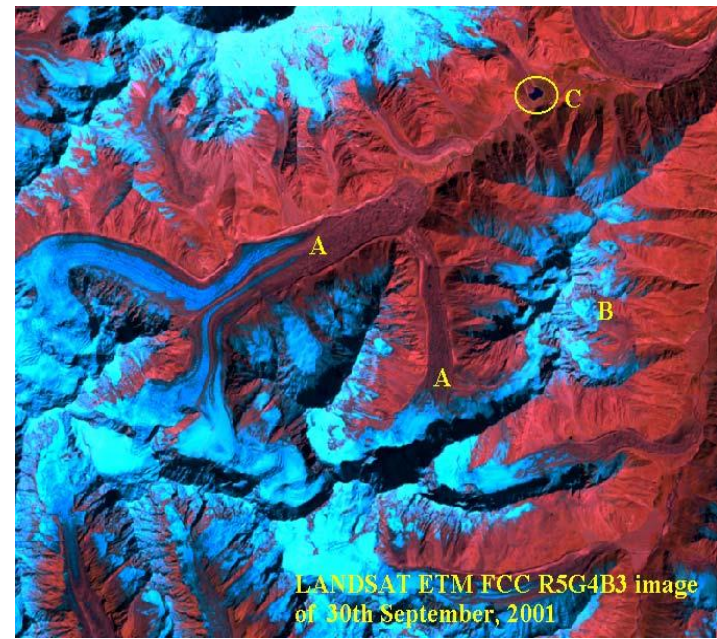

Fig. 3. Subset of landsat-7 ETM images of the study area. Glacier ice covers with debris (A), Snow (B) and Glacial lake (C).

\section{J. Glaciation Characteristics}

The Central Himalayas receive moisture from the summer monsoons and the western Himalayas from winter and summer fronts. Formation of glaciers is subjected to severe climate. The growth and inception of glaciers is credited to the climate. One of the causes of glacier occurrence is the form of landscape which in turn becomes a threshold of fundamental importance for determination of underneath morphology of glacier. Different size \& shape glaciers are formed with respect to landscape involving climatic conditions for glaciation. Zones of maximum precipitation involving climatic fronts engulf mountain glaciated regions.

Some of the steepest gradients glaciers in the world are found in Karakoram and Himalayan region of Pakistan. These are high activity glaciers involving toughest terrain friction. These glaciers are grouped in three categories according to the patterns of their movement:-

1) Steady movement glaciers.

2) Short steep crevasses glaciers having cyclic advances.

3) Catastrophic advancing surging glaciers.

\section{K. Glaciers of Shyok River Basin}

This basin has high peaks with the elevation of more than 7,000 masl. About $34.67 \%$ of the total 10,235 sq. $\mathrm{km}$ area of the basin is under the glacier cover. Out of 372 glaciers in the basin $14 \%$ are the Valley glaciers and $86 \%$ are the mountain type glaciers. The huge size glaciers like Siachin, Kondus, Bilafond, Ghandogoro and Masherbrum are concentrated in this basin as shown in Fig. 4.

\section{Glacial Avalanche Hazard Analysis of Shyok Basin}

This basin comprises of an ice reserves of $892 \mathrm{~km} 3$ and glaciated area of about $3,548 \mathrm{~km} 2$. Snowmelt dominates over glacial melt in the rivers draining the western Greater 
Himalayas and the Hindu Kush [7]. The presence of mountainous types of the glaciers pronounces the hazard of glacial avalanche.

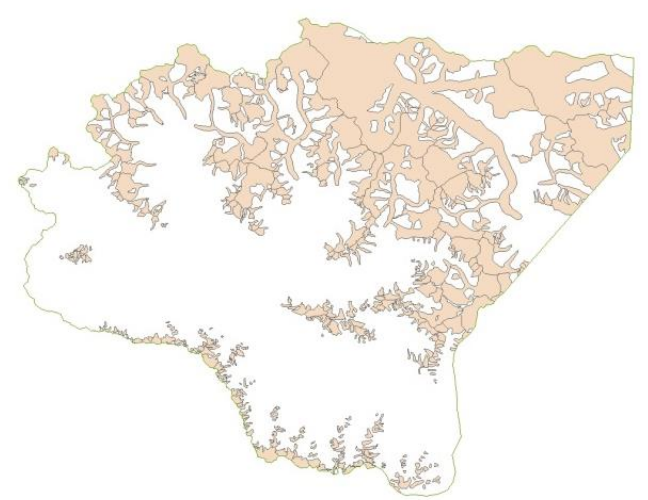

Fig. 4. Glaciers distribution in Shyok river basin.

The biggest valley glacier of this basin is Siachen with an area of $1,112 \mathrm{sq}$. km. Few large size Valley glaciers in Shyok river basin involve several supra glacial lakes as shown in Fig. 5. Historically unprecedented global glacier decline is observed in the early 21 st century [8]. The Mountain glaciers are also of large size. The largest Mountain glacier has an area of more than 32.67 sq. $\mathrm{km}$. The contribution of Mountain glaciers in the total glacier area is more than $13 \%$ as shown in Table I.

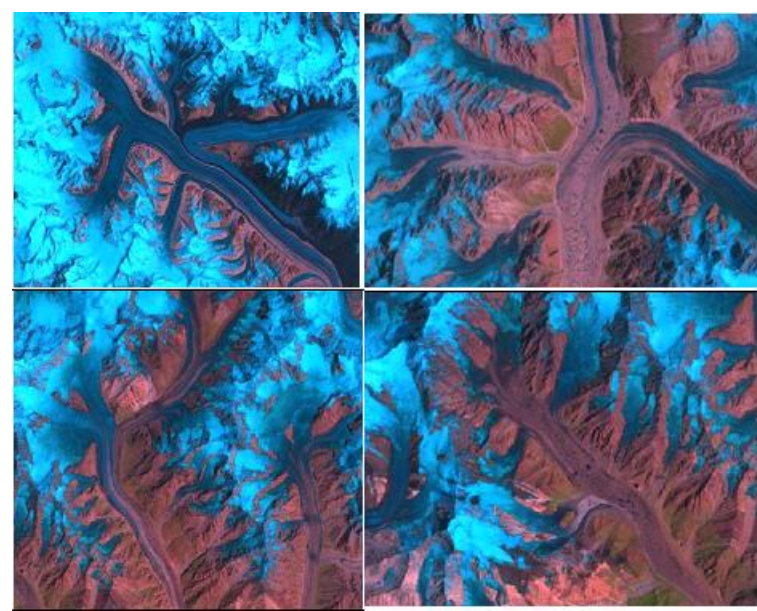

Fig. 5. Valley glaciers in Shyok River basin in FCC 5(R)4(G)2(B).

TABLE I: DETAILS OF VARIOUS TYPES OF GLACIERS OF SHYOK RIVER BASIN

\begin{tabular}{|c|c|c|c|c|c|c|c|c|}
\hline \multirow{2}{*}{$\begin{array}{l}\text { Glacier } \\
\text { Type }\end{array}$} & \multicolumn{2}{|l|}{ Number } & \multicolumn{2}{|l|}{ Area $\left(\mathrm{km}^{2}\right)$} & \multicolumn{2}{|l|}{ Length (m) } & \multicolumn{2}{|c|}{ Ice Reserves $\left(\mathrm{km}^{3}\right)$} \\
\hline & Total & $\%$ & Total & $\%$ & Min & Max. & Total & $\%$ \\
\hline Ice apron & 13 & 3.5 & 9.14 & 0.3 & 398 & 1437 & 0.35 & 0.04 \\
\hline Ice cap & 32 & 8.6 & 26.11 & 0.7 & 368 & 2835 & 1.18 & 0.13 \\
\hline Mountain & 143 & 38.4 & 471.06 & 13.3 & 353 & 11311 & 38.16 & 4.28 \\
\hline Niche & 71 & 19.1 & 72.69 & 2.1 & 288 & 5014 & 3.56 & 0.40 \\
\hline Valley & 52 & 14.0 & 2914.15 & 82.1 & 540 & 76641 & 845.98 & 94.86 \\
\hline Total & 372 & & 3547.84 & & & & 891.80 & \\
\hline
\end{tabular}

TABLE II: GLACIERS DISTRIBUTION UNDER VARIOUS ASPECTS IN SHYOK RIVER BASIN

\begin{tabular}{|c|c|c|c|c|c|c|c|c|}
\hline \multirow{2}{*}{$\begin{array}{l}\text { Aspect } \\
\text { (Glacier Orientation) }\end{array}$} & \multicolumn{2}{|l|}{ Number } & \multicolumn{2}{|l|}{ Area $\left(\mathrm{km}^{2}\right)$} & \multicolumn{2}{|c|}{ Length (m) } & \multicolumn{2}{|c|}{ Ice Reserves $\left(\mathrm{km}^{3}\right)$} \\
\hline & Total & $\%$ & Total & $\%$ & Min. & Max. & Total & $\%$ \\
\hline $\mathrm{N}$ & 48 & 12.9 & 111.63 & 3.15 & 390 & 5348 & 7.802 & 0.87 \\
\hline $\mathrm{NE}$ & 70 & 18.82 & 311.35 & 8.78 & 552 & 15085 & 44.975 & 5.04 \\
\hline $\mathrm{E}$ & 57 & 15.32 & 471.04 & 13.28 & 288 & 30587 & 107.603 & 12.07 \\
\hline SE & 48 & 12.9 & 1656.52 & 46.69 & 540 & 76641 & 576.934 & 64.69 \\
\hline $\mathrm{S}$ & 57 & 15.32 & 500.74 & 14.11 & 533 & 21362 & 87.127 & 9.77 \\
\hline SW & 30 & 8.06 & 198.98 & 5.61 & 548 & 18219 & 25.507 & 2.86 \\
\hline W & 9 & 2.42 & 23.63 & 0.67 & 1135 & 5353 & 1.658 & 0.19 \\
\hline NW & 53 & 14.25 & 273.95 & 7.72 & 265 & 19948 & 40.195 & 4.51 \\
\hline Total & 372 & & 3547.84 & & & & 891.801 & \\
\hline
\end{tabular}

Aspect wise the glaciers are distributed uniformly except the $\mathrm{W}$ and SW. The larger glaciers like Siachen, Kondus, Bilafond, Ghandogoro and Masherbrum are facing SE and S aspects having the maximum glacier area. The E and NE also have higher percentage of total glacier area. Generally the total length of the glaciers is more than $100 \mathrm{~km}$ except for W and $\mathrm{N}$. The glaciers on southeastern aspect have a total length of $254.3 \mathrm{~km}$ as shown in Table II.

It is evident from the study that the aspect zones $\mathrm{E}$ and $\mathrm{SE}$ in comparison with other aspect zones of the basin hold greater area. The southern aspect zones have maximum melting activities which can cause some catastrophic events like glacial avalanche in combination with other factors like anthropogenic activities, high temperature and seismic.

After having applied the filter of orientation to the glaciers of Shyok basin as shown in Fig. 6, further segregation of glaciers in Shyok basin with dangerous slope is carried out with application of a filter of slope from 300 to 450 which is considered to be unstable for the glaciers as shown in Fig. 7.

Finally the glacial hazard in Shyok basin is carried out with application of another filter of elevation of the glaciers being less than $14000 \mathrm{ft}$ height from mean sea level which is considered to be a cause of glacial melt and thus these glaciers are more prone a trigger of glacial avalanche as 
shown in Fig. 8.

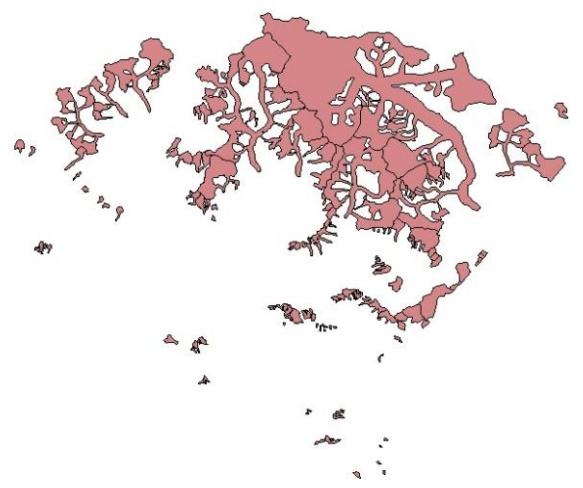

Fig. 6. Glaciers in Shyok basin with southern aspect.

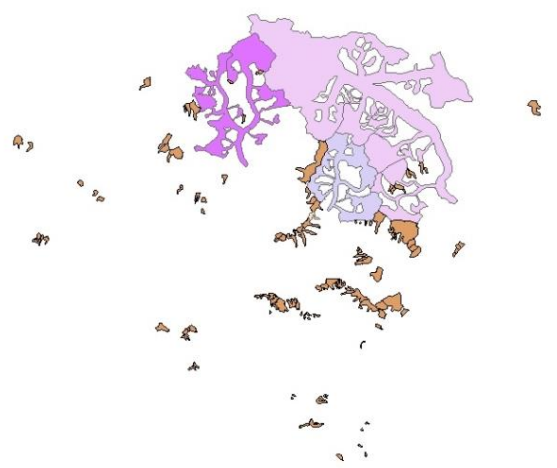

Fig. 7. Glaciers in Shyok basin with dangerous slope (brown).

\section{Glaciers of Shigar River Basin}

The basin encompasses about 2,240 sq. km glacier area out of about 7,382 sq. km total area. The basin has 194 glaciers out of which around $30 \%$ are Mountain glaciers as shown in Fig. 9. These 194 glaciers cover $30.34 \%$ of the total basin area. The N, NE and NW aspects engulf large size glaciers.

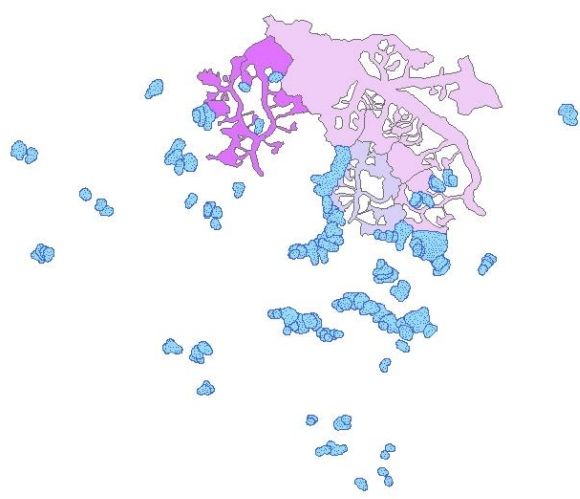

Fig. 8. Glaciers hazard in Shyok basin (blue).

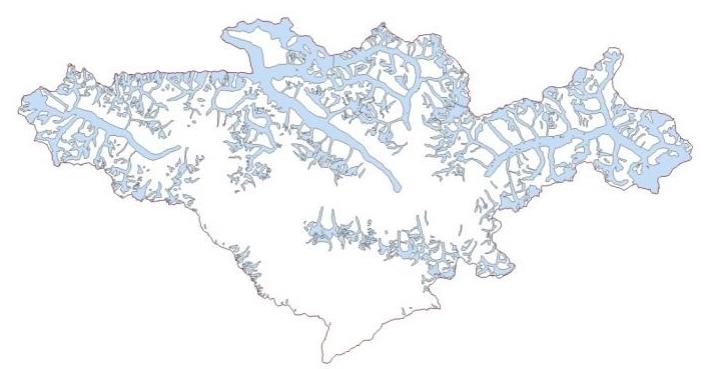

Fig. 9. The Glaciers distribution in the Shigar river basin.

\section{N. Glacial Avalanche Hazard Analysis of Shigar Basin}

This basin comprises of an ice reserves of $581 \mathrm{~km} 3$ and glaciated area of about 2,240 km2 as shown in Table III. The presence of mountainous types of the glaciers pronounces the hazard of glacial avalanche.

The Valley glaciers contribute $93 \%$ of the total glacier area followed by Mountain glaciers contributing 5\% to the glacier area. The largest Valley glaciers are Baltoro, Biafo, Panmah and Chogo lungma as shown in Fig. 10. The length of Baltoro glacier is about $60 \mathrm{~km}$ and it has the maximum area of about $641 \mathrm{sq}$. km. The length of Biafo glacier is about $62 \mathrm{~km}$ with an area of 426 sq. $\mathrm{km}$.
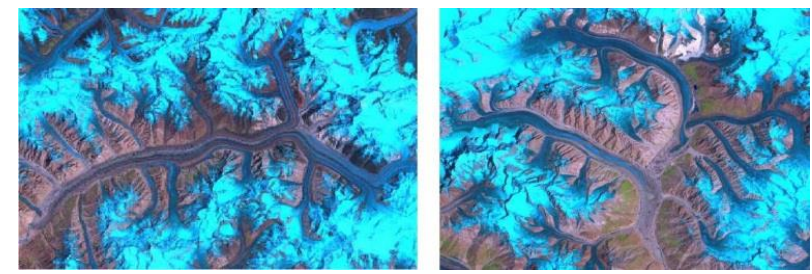

Fig. 10. Typical large size and complex valley glaciers in Shigar River basin

The details of the glaciers distribution of on various aspects are presented in Table IV. Overall the glaciers are distributed uniformly in all directions. The maximum number of glaciers (38) is on the NE aspect while minimum number (16) is on the western aspect. The maximum glacier area $(49.6 \%)$ is on the SE aspect followed by $31 \%$ on the western aspect. Rest of the area is distributed on all other directions. The extensive area on SE is due to the fact that most of the large Valley and Mountain glaciers are oriented towards this aspect.

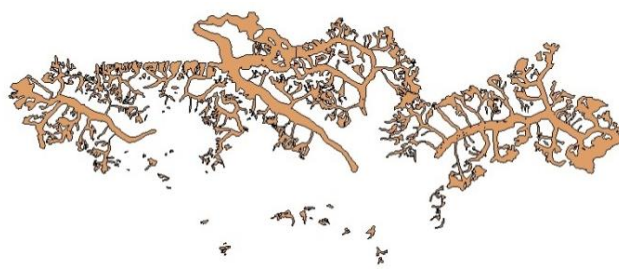

Fig. 11. Glaciers in Shigar basin with southern aspect.

It is evident from this study that in comparison with other aspect zones the aspect zones SE and W hold greater area of the basin. Southern aspect zones have maximum melting rate which may cause triggering of some catastrophic event like glacial avalanche coupled with other factors like anthropogenic activities, high temperature and seismic activity.

After having applied the filter of orientation to the glaciers of Shigar basin as shown in Fig. 11, further segregation of glaciers in Shigar basin with dangerous slope is carried out with application of a filter of slope from 300 to 450 which is considered to be unstable for the glaciers as shown in Fig. 12.

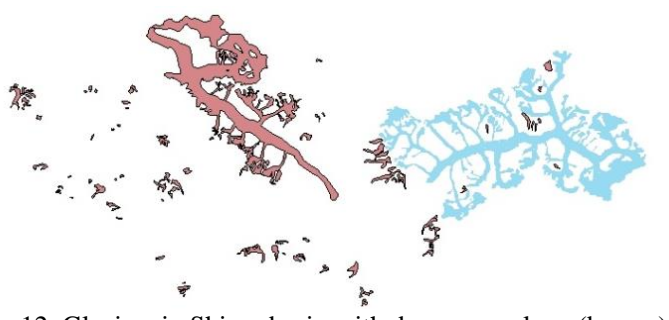

Fig. 12. Glaciers in Shigar basin with dangerous slope (brown) 
Finally the glacial hazard in Shigar basin is carried out with application of another filter of elevation of the glaciers being less than $14000 \mathrm{ft}$ height from mean sea level which is considered to be a cause of glacial melt and thus these glaciers are more prone to a trigger of glacial avalanche as shown in Fig. 13.

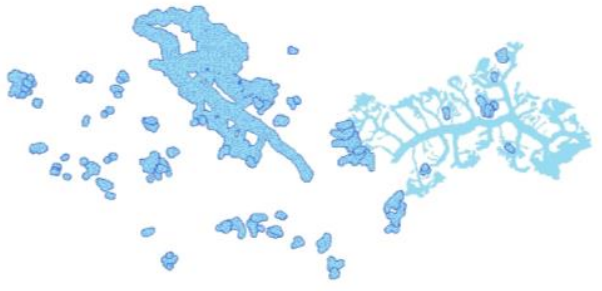

Fig. 13. Glaciers hazard in Shigar basin (blue).

TABLE III: DETAILS OF VARIOUS TYPES OF GLACIERS OF SHIGAR RIVER BASIN

\begin{tabular}{|c|c|c|c|c|c|c|c|c|}
\hline \multirow{2}{*}{$\begin{array}{l}\text { Glacier } \\
\text { Type }\end{array}$} & \multicolumn{2}{|l|}{ Number } & \multicolumn{2}{|l|}{ Area $\left(\mathrm{km}^{2}\right)$} & \multicolumn{2}{|l|}{ Length (m) } & \multicolumn{2}{|c|}{ Ice Reserves $\left(\mathrm{km}^{3}\right)$} \\
\hline & Total & $\%$ & Total & $\%$ & Min. & Max. & Total & $\%$ \\
\hline Cirque & 34 & 17.5 & 25.69 & 1.1 & 250 & 6460 & 1.146 & 0.197 \\
\hline Ice apron & 4 & 2.1 & 0.92 & 0.0 & 380 & 1215 & 0.022 & 0.004 \\
\hline Ice cap & 3 & 1.5 & 0.56 & 0.0 & 392 & 754 & 0.012 & 0.002 \\
\hline Mountain & 58 & 29.9 & 102.36 & 4.6 & 290 & 6354 & 6.257 & 1.076 \\
\hline Niche & 49 & 25.3 & 29.01 & 1.3 & 344 & 3850 & 1.121 & 0.193 \\
\hline Valley & 46 & 23.7 & 2081.54 & 92.9 & 2670 & 62624 & 572.71 & 98.528 \\
\hline Total & 194 & & 2240.08 & & & & 581.27 & \\
\hline
\end{tabular}

TABLE IV: GLACIERS DISTRIBUTION WITH DIFFERENT ASPECTS IN SHIGAR RIVER BASIN

\begin{tabular}{|c|c|c|c|c|c|c|c|c|}
\hline \multirow{2}{*}{$\begin{array}{l}\text { Aspect } \\
\text { (Glacier } \\
\text { Orientation) }\end{array}$} & \multicolumn{2}{|l|}{ Number } & \multicolumn{2}{|l|}{ Area $\left(\mathrm{km}^{2}\right)$} & \multicolumn{2}{|l|}{ Length (m) } & \multicolumn{2}{|l|}{ Ice Reserves $\left(\mathrm{km}^{3}\right)$} \\
\hline & Total & $\%$ & Total & $\%$ & Min. & Max. & Total & $\%$ \\
\hline $\mathrm{N}$ & 26 & 13.40 & 97.64 & 4.36 & 290 & 13123 & 9.98 & 1.72 \\
\hline $\mathrm{NE}$ & 38 & 19.59 & 79.97 & 3.57 & 469 & 8559 & 5.81 & 1.00 \\
\hline $\mathrm{E}$ & 27 & 13.92 & 36.70 & 1.64 & 250 & 6460 & 2.42 & 0.42 \\
\hline SE & 32 & 16.49 & 1111.14 & 49.60 & 344 & 62624 & 304.69 & 52.42 \\
\hline$S$ & 17 & 8.76 & 124.54 & 5.56 & 724 & 15324 & 16.67 & 2.87 \\
\hline SW & 17 & 8.76 & 41.60 & 1.86 & 392 & 6675 & 2.85 & 0.49 \\
\hline W & 16 & 8.25 & 693.86 & 30.97 & 355 & 58970 & 234.79 & 40.39 \\
\hline NW & 21 & 10.82 & 54.63 & 2.44 & 604 & 8233 & 4.07 & 0.70 \\
\hline Total & 194 & & 2240.08 & & & & 581.27 & \\
\hline
\end{tabular}

\section{CONCLUSION}

The significance of the glacial avalanches lies especially in the exceptional risk to infrastructures and human communities. The dynamic character of glacial avalanches greatly magnifies their erosion competence and capacity. A large numbers of landslides on terraces and valley sides coupled with glacial hazards have been reported.

The Shyok basin is more prone to glacial avalanche hazards in comparison with Shigar basin based on the location of glacier vis-a-vis infrastructure, orientation of the glacier surface, slope of the glaciated mass, geomorphology of underneath surface, geocover of vicinity, crevasses, ice melt, elevation and anthropogenic activities.

The settlements located on the margins of an alluvial fan are under threat of debris flow and glacial mass movement thus making very high occurrence of the probability.

There are possible methods for glacial avalanche hazards impact mitigation and for establishing the early warning systems. In order to protect downstream infrastructure against the destructive forces of glacial avalanches in glacial hazard prone areas, pre disaster measures should be taken. In downstream areas the installation of such monitoring system be ensured to protect the infrastructures prior to, during and after the construction.
The further study of damming materials including the surrounding conditions is very essential in choosing an appropriate method to start any mitigation measure. Careful evaluation by future detailed studies of the mountainous glaciers is very vital in this regard. The measures taken in future must be such that these should not create or increase the risk of a glacial avalanche hazard during and after the mitigation measures are in place. Physical monitoring systems of the glaciers and the surroundings are necessary at different stages during and after the mitigation process.

\section{REFERENCES}

[1] R. Bhambri et al., "Heterogeneity in glacier response in the upper Shyok valley, northeast Karakoram," The Cryosphere, vol. 7, no. 5, 1385-1398, 2013.

[2] M. R. Bhutiyani, "Mass-balance studies on Siachin Glacier in the Nubra valley, Karakoram Himalaya, India,” Journal of Glaciology, vol. 45, no. 149 , pp. $112-118,1999$.

[3] M. B. F. Bundesministrium, Characteristics of the Alpine Climate, Glaciers and Permafrost, CIPRA Publications, 2003.

[4] S. P. Joshi et al., Inventory of Glaciers, Glacial Lakes and Glacial Lake Outburst Flood Monitoring and Early Warning System in the Hindu Kush-Himalayan Region, Nepal, p. 364, Kathmandu, Nepal, 2001.

[5] A. Khan et al., "The upper Indus basin," Journal of Hydrology, vol. 509, pp. 442-453, 2014.

[6] LIGG/WECS/NEA, Report on the First Expedition to Glaciers and Glacier Lakes in the Pumqu (Arun) and Poique (Bhote-Sun Kosi) River Basins, Xizang (Tibet), China, Sino-Nepalese Investigation of Glacier 
Lake Outburst Floods in the Himalaya, Beijing, China: Science Press, 1988.

[7] B. Mukhopadhyay and A. Khan, "Re-evaluation of snowmelt and glacial melt in river flows in Upper Indus Basin and its significance in changing climate," Journal of Hydrology, 2015.

[8] M. Zemp et al., "Historically unprecedented global glacier decline in the early 21 st century," J. Glaciol., vol. 61, no. 228, pp. 745-762, 2015.

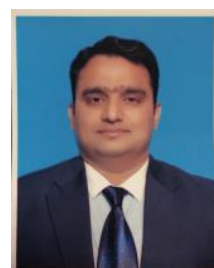

N. Gilany was born on April 2, 1976. He got the MS (RS\&GIS), IGIS, NUST, Islamabad, Pakistan, 2011. The major field of study is alpine glaciers of northern areas of Pakistan.

$\mathrm{He}$ is vastly experienced in the field of glaciology. He works as visiting faculty of NUST. Currently he is enrolled as PhD scholar of IGIS, NUST. His area of research is glacial hazards of Shigar and Shyok basins of Pakistan.

Mr. Gilany has got presidential award on his professional work. His scientific studies are well acknowledged by the state. 